\title{
Tissue Recombination Models for the Study of Epithelial Cancer
}

\author{
Yang Zong, ${ }^{1}$ Andrew S. Goldstein, ${ }^{2,3,5,6,7}$ and Owen N. Witte ${ }^{1,2,4,5,6}$ \\ ${ }^{1}$ Howard Hughes Medical Institute, University of California, Los Angeles, California 90095; ${ }^{2}$ Department of \\ Molecular and Medical Pharmacology, University of California, Los Angeles, California 90095; ${ }^{3}$ Department of \\ Urology, University of California, Los Angeles, California 90095; ${ }^{4}$ Department of Microbiology, Immunology, and \\ Molecular Genetics, University of California, Los Angeles, California 90095; ${ }^{5}$ Jonsson Comprehensive Cancer \\ Center, David Geffen School of Medicine, University of California, Los Angeles, California 90095; ${ }^{6}$ Eli and Edythe \\ Broad Center of Regenerative Medicine and Stem Cell Research, University of California, Los Angeles, California \\ 90095
}

Animal models of cancer provide fundamental insight into the cellular and molecular mechanisms of human cancer development. As an alternative to genetically engineered mouse models, increasing evidence shows that tissue recombination and transplantation models represent an efficient approach to faithfully recapitulate solid epithelial cancer in mice. Cancer can be rapidly initiated through lentiviral delivery of defined genetic alterations into target cells that are grown in a physiological milieu with an appropriate epithelial-stromal interaction. Through genetic manipulation of distinct subpopulations of epithelial cells and mesenchymal cells, this powerful system can readily test both cell-autonomous roles of genetic events in the epithelial compartment and the paracrine effects of the microenvironment. Here we review the recent advances in mouse models of several epithelial cancers achieved using orthotopic transplantation and tissue recombination strategies, with an emphasis on the dissociated cell in vivo prostate regeneration model to investigate prostate cancer.

Investigation of critical elements underlying human cancer development requires in vivo model systems. Attempts to inoculate experimental animals with representative fragments of human tumors have been recorded since the mid-1800s (McConnell 1908; Woolley 1958). Although there were a few examples of successful heterotransplantation, the vast majority of these early studies ended up with negative results (McConnell 1908). Immune responses associated with the heterologous transfer of human tissues are the predominant mechanism for the rejection of transplanted grafts. A significant advance in overcoming the immune response was made with mice genetically engineered with mutations resulting in the loss of functional inflammatory cells. Multiple strains of immunodeficient mice-including nude $(\mathrm{Nu} / \mathrm{Nu})$ (Pantelouris 1968), beige ( $\mathrm{Lyst}^{\mathrm{bg}}$ ) (Gallin et al. 1974; Roder 1979), and various subtypes of severe combined immunodeficient mice (SCID, Prkdc $c^{\text {scid }}$ ) such as C.B17 SCID (Dorshkind et al. 1984), NOD SCID (Shultz et al. 1995), and NOD SCID gamma (NSG) (Shultz et al. 2005)—have become the most commonly used hosts for generating human cancer xenografts.

With the availability of these immunodeficient mice, heterologous transplantation of human cancers is generally performed as subcutaneous inoculation under the skin of host mice. However,

\footnotetext{
${ }^{7}$ Correspondence: andrew.goldstein@ucla.edu

(C) 2015 Cold Spring Harbor Laboratory Press

Cite this introduction as Cold Spring Harb Protoc; doi:10.1101/pdb.top069880
} 
given the critical microenvironmental influences on tumorigenesis (Bhowmick et al. 2004; Joyce and Pollard 2009; Bissell and Hines 2011), it is well accepted that the supportive microenvironment of transplantation sites and the inductive effects of surrounding stromal tissues also play important roles in transplantation-based models of human epithelial cancer. We will discuss the advantages and limitations of orthotopic xenografting and tissue recombination approaches, mainly using the mammary fat pad transplantation and the dissociated prostate in vivo regeneration as examples.

It is impossible to ignore the pioneering research in hematological malignancies that led to transplantation-based models of solid epithelial cancers. The relative ease with which primary human leukemic cells can be isolated from peripheral blood and bone marrow has allowed the identification of genetic alterations and cell populations critical for blood-based disease development and progression. To validate the function of genetic changes in vivo, many murine models of various leukemias and other myeloproliferative disorders have been successfully established using retroviral transduction and bone marrow transplantation (Daley et al. 1990; Kelliher et al. 1990; Kroon et al. 1998; Wernig et al. 2006). These transplantation-based models of hematological malignancies have proven to be very useful in bettering our understanding of leukemogenesis and testing novel therapeutic strategies.

Despite some differences in etiology and disease evolution between leukemias and solid epithelial cancers, a growing body of evidence shows that solid epithelial cancers can also be faithfully recapitulated in mice by coupling virological tools with tissue recombination/transplantation approach techniques. We will explore how solid epithelial cancers have been studied in a manner analogous to leukemia, using tissue recombination and transplantation to mix and match different genetic events with different target cell populations to model the development of human cancers in mice.

\section{TUMOR XENOGRAFTS GROWN IN ORTHOTOPIC VERSUS SUBCUTANEOUS SITES}

In the traditional xenograft model of human cancers, in vitro cultured cancer cells are injected into immunodeficient mice subcutaneously, resulting in the formation of palpable and visible lumps at the transplantation site over a period of time ranging from weeks to many months. Owing to the low cost, ease of use, and the convenience of monitoring tumor growth in live recipients, the subcutaneous xenograft approach has extensively been used in the solid tumor biology field. Although it remains a useful strategy to dissect the complexity of signaling pathways in cancer and to identify novel therapeutic agents, some subcutaneous xenograft models do not have good clinical correlations and fail to consistently predict drug responses (Kuo et al. 1993; Sharpless and Depinho 2006; Talmadge et al. 2007). The major mechanism for the compromised clinical relevance of subcutaneous xenograft models is the fact that human cancer cells are transferred into a nonphysiological site, where cancer cells are rapidly grown with the support of reactive stroma and neovasculature from host mice. Owing to the infiltration of host cells not typically found in the tissue site of interest and the absence of an appropriate interaction between cancerous epithelial cells and their native microenvironment, ectopic subcutaneously implanted tumors poorly reproduce the biological behavior and clinical response of human cancers (Sharpless and Depinho 2006; Talmadge et al. 2007).

Orthotopic transplantation places cancer cells into the corresponding sites where cancer would be expected to arise naturally. This improved approach provides local signals that are lacking in a subcutaneous milieu and allows the propagation of a human cancer of interest in a relevant tissue context. Because the approach provides more physiological tumor-stroma interaction and communication with neighboring normal cells in the anatomically matched organ, orthotopic xenograft studies can more closely recapitulate the biological aspects of cancer growth in humans when compared with the subcutaneous inoculation model. Many studies using this technique have been reported to successfully model cancers of various tissue origins, including the lung, breast, prostate, bladder, colon, pancreas, and brain (Kaye et al. 1986; Capella et al. 1999; Hoffman 1999; Chan et al. 2009).

By parallel comparison of subcutaneous and orthotopic xenografts, significant differences in tumor behavior between the two approaches have been described (Nakajima et al. 1990; Deramaudt 
et al. 2006; Fleming et al. 2010). The orthotopic tumors tend to grow more rapidly, with enhanced properties of local invasion and remote metastasis. In some orthotopic transplantation models of human cancers, spontaneous metastatic disease can be observed in their clinically relevant target organs (Yang et al. 1999; Kuperwasser et al. 2005). Dissemination that follows natural routes can be achieved in orthotopic models to generate multiple metastatic lesions, especially if the primary tumors are surgically removed, which prolongs survival and thus allows sufficient time for previously seeded cancer cells to grow into advanced metastases (Munoz et al. 2006; Francia et al. 2011).

Orthotopic tumor growth cannot be measured as readily as subcutaneous tumors and often requires complex imaging modalities to noninvasively monitor progression and metastasis (Weissleder 2002; Condeelis and Weissleder 2010). Although such experiments may be more time-consuming and expensive than monitoring the standard subcutaneous xenografting approach, orthotopic transplantation provides a more faithful platform for studying the genetic and biological evolution of human cancers. Orthotopic systems could also be a more reliable predictive tool for testing anticancertargeted compounds for clinical effectiveness, particularly when examining the efficacy of drugs to treat late-stage cancers as well as potential agents against tumor stroma and host immune components.

\section{MAMMARY FAT PAD AS AN ORTHOTOPIC SITE FOR STUDYING BREAST CANCER}

For breast cancer and mammary gland biology analogous to the human breast, the most widely used anatomic location in transplantation-based studies has been the mammary fat pad (MFP) in female mice. More than a half-century ago, Deome et al. (1959) first showed that normal murine mammary tissue transplanted into recipient mice could regenerate normal hormone-responsive gland structures only when the tissue was engrafted into the MFP. By comparison to subcutaneous transplantation, the growth-promoting effects of the MFP were well illustrated in this study, which showed that the incidence of tumors derived from hyperplastic alveolar nodules was much higher when this precancerous tissue was transplanted into the MFP than into the dorsal subcutis of syngeneic mice. The MFP, especially the fourth of the five paired MFPs, has since become the predominant transplantation site for many studies of mammary gland development and breast cancer.

The elegant work of DeOme and his coworkers was based on their fundamental observations of normal murine mammary gland development, wherein the majority of ductal outgrowth in the MFP occurs after puberty. It has been shown that the MFP arises in the mouse embryo as a large sheet of condensed mesenchyme at Day 14 of gestation. The majority of the MFP is devoid of mammary glandular parenchyma until after puberty. At puberty, the growing ducts elongate to progressively fill the entire MFP (Sakakura et al. 1982, 1987; Neville et al. 1998). This developmental pattern allows scientists to surgically resect the part of the MFP ( $\sim 20 \%$ by area) that is filled with mammary epithelial glands in weanling female mice ( $3 \mathrm{wk}$ of age). The "cleared" MFP will not contain any residual mammary glandular structure as the mice mature and provides an optimal space to introduce donor epithelial cells into their native microenvironment (see Protocol: The Cleared Mammary Fat Pad Transplantation Assay for Mammary Epithelial Organogenesis [Lawson et al. 2014]).

These key findings have opened a new field for the study of mammary stem cells and the etiology of breast cancer. Using the technique of transplantation into the murine MFP, both normal stem cells (Kordon and Smith 1998; Shackleton et al. 2006; Stingl et al. 2006) and tumor initiating cells (Al-Hajj et al. 2003; Ginestier et al. 2007; Zhang et al. 2008) in mammary epithelium have been prospectively identified over the last few decades. The cellular hierarchy of mammary stem/progenitor cells during physiological conditions (Van Keymeulen et al. 2011) and the hormonal influences on the pool size and regenerative activity of mammary stem cells (Asselin-Labat et al. 2010; Joshi et al. 2010) have been revealed by mammary reconstitution assays, using the cleared MFP as the standard site in host mice. By coupling this orthotopic transplantation technique with genetic manipulation of short-term cultured primary mammary epithelial cells via retroviral transduction, an ex vivo mammary reconstitution assay has been established to model the initiation step of breast cancer in mice (Edwards et al. 1996). The functions of several genes associated with breast cancer development, such as myc 
(Edwards et al. 1988), ErbB2 (Bradbury et al. 1993), Wnt-1 (Edwards et al. 1992), and Wnt-4 (Bradbury et al. 1995) have been tested in this system. Moreover, the reciprocal transplantation approach using mammary epithelial cells and gland-free MFP from knockout and wild-type mice also makes it feasible to distinguish the definite effects of the epithelial-intrinsic and stromal responses to various hormones and growth factors on the process of mammogenesis (Brisken et al. 1998; Wiesen et al. 1999; Gallego et al. 2001; Mallepell et al. 2006).

Using the MFP transplantation approach, the microenvironmental contribution of genetic changes in the stroma to mammary tumorigenesis has also been evaluated (Barcellos-Hoff and Ravani 2000; Medina 2010). For example, it has been shown that Ets2 deficiency in the stroma of the MFP suppresses mammary tumor growth induced by polyomavirus middle T (PyMT) oncogene, which is correlated with decreased macrophage expression of matrix metalloproteinases Mmp3 and Mmp9 (Man et al. 2003). Recently, the function of stromal Mmp9 expression has been directly tested by orthotopically transplanting murine mammary tumors into $\mathrm{Mmp}^{-/-}$host mice, showing that loss of Mmp9 in the stroma not only results in slower tumor growth but also sensitizes tumors to doxorubicin treatment (Nakasone et al. 2012). In summary, orthotopic transplantation into the MFP is a very useful tool to investigate the cellular basis and molecular mechanisms for normal mammary development as well as breast cancer evolution.

\section{TISSUE RECOMBINATION MODELS TO MIMIC THE NATIVE TUMOR MICROENVIRONMENT}

In addition to orthotopic transplantation into normal anatomic sites, tissue recombination of epithelia and mesenchyme of relevant origins can also provide an appropriate physiological milieu for the growth and progression of solid epithelial tumors. Starting in the 1950s, developmental biologists revealed that tissue morphogenesis requires reciprocal interactions between the epithelial and mesenchymal compartments, and that the mesenchyme plays critical roles in the induction and patterning of epithelial development (Grobstein 1953a,b; Auerbach 1960; Alescio and Cassini 1962; Fleischmajer 1967). Building on these findings in mice, the pioneering work by Cunha and colleagues provided the seminal observations about mesenchymal-epithelial interactions in hormonal responses in the normal development of sex hormone-regulated peripheral tissues, including prostate (Cunha and Lung 1978), seminal vesicle (Cunha 1972a,c), and salivary gland (Cunha 1972b).

From these studies, a very useful system of tissue recombination has been developed for the analysis of epithelial development, most notably in the mouse prostate. Tissue fragments mechanically dissected from rodent embryonic urogenital sinus mesenchyme (UGSM) at mid-gestation provide potent inductive influences to support prostate epithelial morphogenesis, when epithelial fragments from urogenital tissue of embryonic or postnatal origin are combined with UGSM cells (Cunha et al. 1980; Norman et al. 1986; Cunha 2008). The anterior chamber of the eyes of adult male mice was initially used as a transplantation site for the grafts, whereas the kidney capsule of immunodeficient mice has been eventually chosen as the preferable site because it offers a rich vascular environment conducive to the robust growth of grafts. The availability of two large kidneys allows for the transplantation of multiple distinct grafts into an individual host, minimizing the number of recipient mice. Tissue recombinants grown under the renal capsule display prostatic branching tubular architecture with secretion-filled ducts that are histologically normal in appearance (Norman et al. 1986).

Compared to orthotopic transplantation of mammary epithelial cells into the MFP, the technical challenge of prostate orthotopic transplantation is considerably higher. The tissue recombination system developed by Cunha and colleagues lowers the demand for surgical skill, but still provides a simulated microenvironment for engrafted epithelial tissues to grow. The system, consisting of prostate tissue fragments and UGSM cells, is a useful model for studying gene function in both the epithelial and mesenchymal compartments in prostate development and prostate carcinogenesis. Several laboratories have used this model to investigate the biological consequences of genetic deletion events commonly found in patient tumors (i.e., $\mathrm{Rb}$ inactivation or loss of $\mathrm{Nkx} 3.1$ ) during prostate cancer initiation (Wang et al. 2000; Kim et al. 2002). 
There are several disadvantages to the tissue fragment recombination assay that have been improved upon using a dissociated cell approach. The bulkiness of tissue fragments blocks widespread cell-cell contact between epithelial and mesenchymal components and prevents subsequent uniform genetic manipulation following the preparation of tissue fragments, resulting in limited flexibility of the system. To overcome these technical restraints, our laboratory modified the tissue recombination system to include enzymatic dissociation of adult prostate tissues into single-cell suspensions, which allows for accurate quantitation, easy labeling, and purification of live cells with cell surface markers (Xin et al. 2005; Lawson et al. 2007; Goldstein et al. 2008) and uniform genetic manipulation by viral vector technologies. After combining dissociated prostate cells from postnatal mice with murine embryonic UGSM cells that have been cultured and propagated short-term in vitro (see Protocol: Preparation of Urogenital Sinus Mesenchymal Cells for Prostate Tissue Recombination Models [Zong et al. 2014a]), collagen plugs containing both epithelial and mesenchymal components are implanted under the kidney capsules of SCID male mice (see Protocol: Dissociated Prostate Regeneration under the Renal Capsule [Zong et al. 2014b; also Xin et al. 2003]). After 4-8 wk of regeneration in vivo, the resulting grafts are filled with glandular tubules, which contain secretion-filled lumens and express a panel of epithelial markers consistent with normal prostate development (Fig. 1). We have also compared different transplantation sites for in vivo regeneration of mouse prostate recombinants and found that tissue recombinants grown under the kidney capsule generate larger grafts relative to those implanted subcutaneously, although no significant differences in the histology of the regenerated tubules were observed (Fig. 2).

Using this dissociated-cell tissue recombination/transplantation assay and incorporating other genetic tools, such as lentivirus-based gene transfer and shRNA-mediated gene knockdown, we have successfully established several prostate cancer models to study the Pten/PI3K/AKT pathway (Xin et al. 2005, 2006; Lukacs et al. 2010). Recently, the biological roles of ETS family transcription factors associated with common gene fusions in human prostate cancer, namely ERG and ETV1, have been tested in our dissociated-cell prostate regeneration system. We found that overexpression of these ETS proteins in adult murine prostate epithelial cells is sufficient to induce the formation of epithelial hyperplasia and focal prostatic intraepithelial neoplasia (PIN) lesions, but not progression to carcinoma (Zong et al. 2009) (Fig. 3A). These observations are similar to the recently reported phenotype of transgenic mice with prostate-specific expression of ERG (Klezovitch et al. 2008; Tomlins et al. 2008) or ETV1 (Tomlins et al. 2007; Shin et al. 2009).

Tissue recombination models of prostate cancer can accurately recapitulate human disease phenotypes and also the neoplastic lesions developed in transgenic mice. Inspired by these encouraging findings, research using the tissue recombination/transplantation technique has been developed to establish models of solid epithelial cancer of several other tissue origins. For example, using an ex vivo cell recombination/subrenal xenografting approach, Abate-Shen and colleagues recently described an invasive bladder cancer model, in which a human bladder cell line is infected with lentiviral vectors encoding RNA interference-mediated knockdown of $p 53$ and PTEN and combined with rat embryonic bladder mesenchyme. This is followed by transplantation under the renal capsule of nude mice (Puzio-Kuter et al. 2009). Similarly, a malleable in vivo endometrial regeneration system has been constructed from dissociated murine uterine epithelium and stroma using the tissue recombination technique. Regenerated endometrial glands in the subrenal grafts respond to pharmacologic variations in a hormonal milieu similar to the native endometrium. Furthermore, using this system, cell-autonomous activation of the PI3-kinase pathway via biallelic loss of PTEN or activation of AKT was found to be sufficient for the initiation of endometrial carcinoma in naïve adult uterine epithelia (Memarzadeh et al. 2010).

\section{STRENGTHS AND WEAKNESSES OF THE TISSUE RECOMBINATION/TRANSPLANTATION MODEL}

We have discussed the orthotopic transplantation and tissue recombination assays for modeling the evolution of solid cancers in mice. It is important to note that genetically engineered mouse models 
A
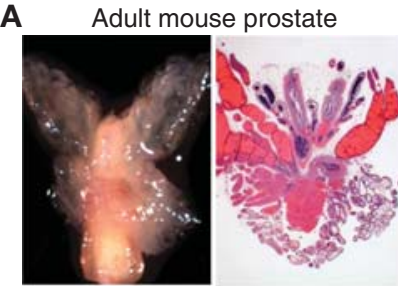

E16 murine pelvic UGS
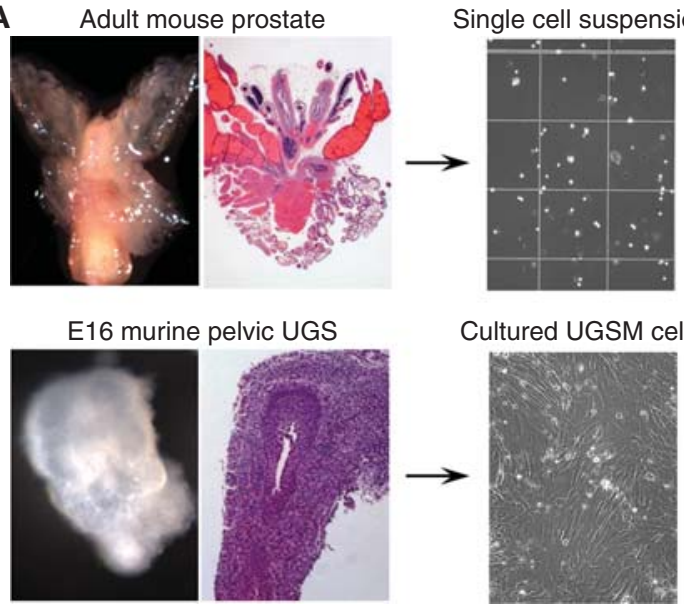

Cultured UGSM cells
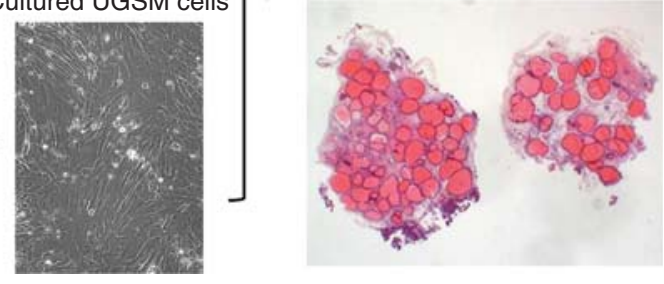

B
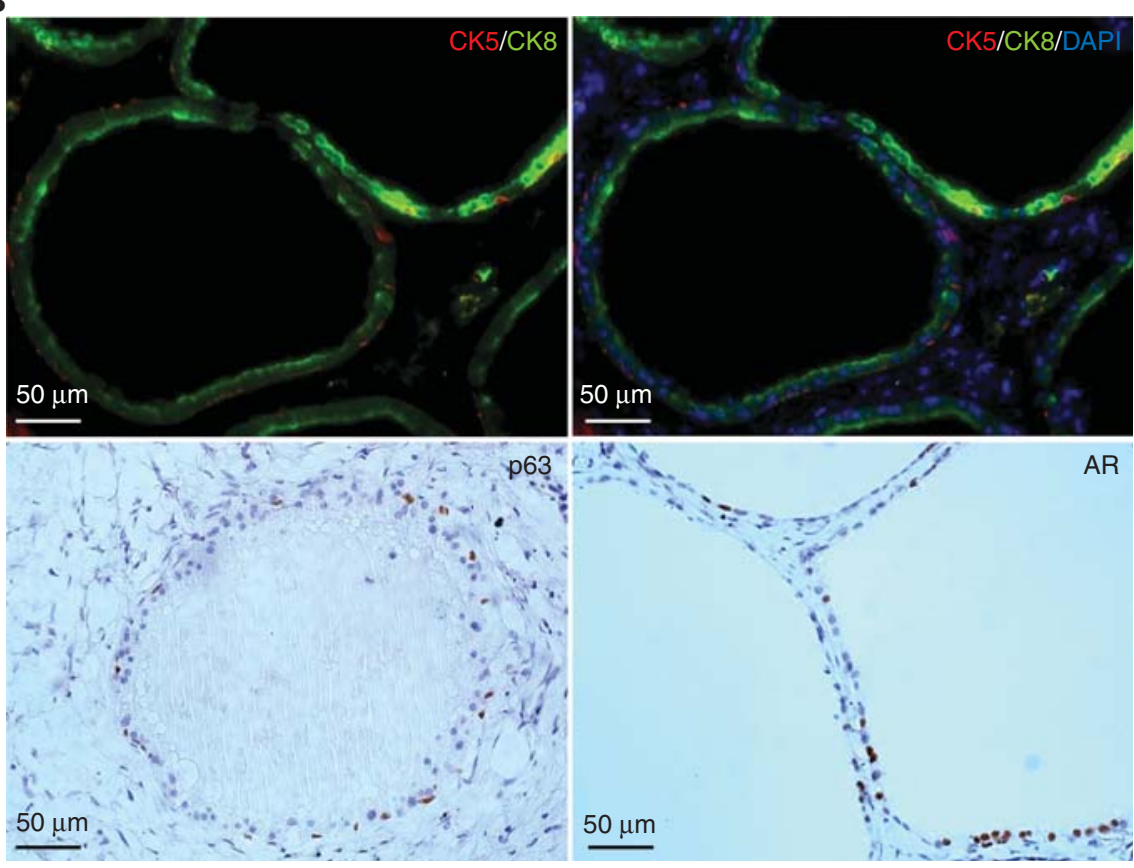

AR

FIGURE 1. Normal glandular tubules regenerated from dissociated adult mouse prostate epithelial cells in the presence of UGSM cells. (A) Schematic design for the dissociated cell in vivo prostate regeneration model. (B) Immunofluorescence and immunohistochemistry analyses of regenerated tubules with antibodies against cytokeratin 5 (CK5), cytokeratin 8 (CK8), p63, and AR.

(GEMMs) represent an alternative approach to study the etiology and pathophysiology of human cancers. Both approaches are quite useful, but have their own advantages and limitations. Because the pros and cons of GEMM and methodologies to improve this powerful tool are discussed thoroughly elsewhere, we will mainly summarize the strengths and drawbacks of the tissue recombination/ transplantation assay.

First, the tissue recombination/transplantation assay is a very flexible system to rapidly produce cancer in mice with high cost-effectiveness. By simply swapping the genes of choice in lentiviral vectors, different forms and mutants of a given oncoprotein or tumor suppressor can be functionally examined in this system. For example, using the lentiviral transduction and tissue recombination technique, it is easy and efficient to test the in vivo roles of several constitutively activated forms and dominant-negative mutants of Src kinase and the related family members in prostate tumorigenesis (Cai et al. 2011b). 

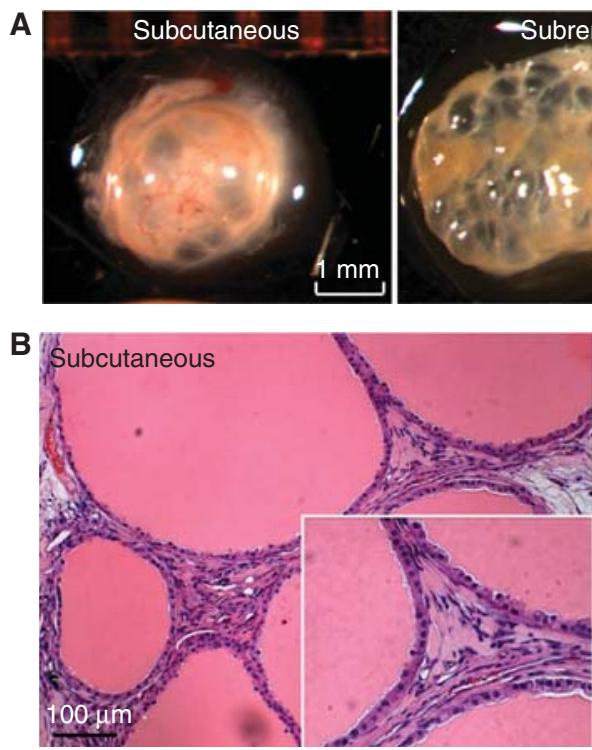
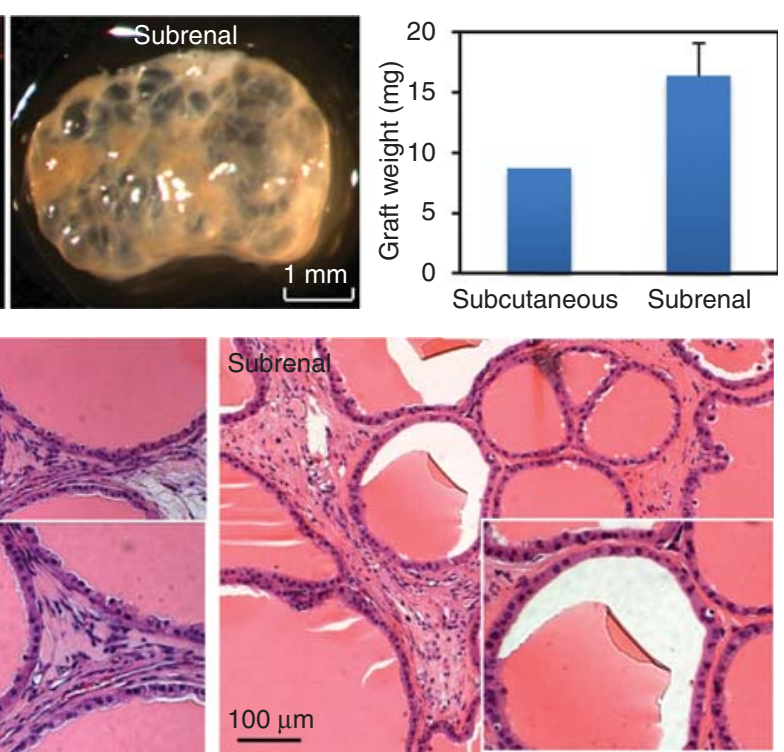

FIGURE 2. Comparison of mouse prostate grafts regenerated in different transplantation sites in SCID mice. (A) Gross appearance and weight measurement of representative prostate grafts grown subcutaneously or under the kidney capsule for 3 mo. (B) Hematoxyline and eosin staining of mouse prostate grafts regenerated in different transplantation sites as indicated.
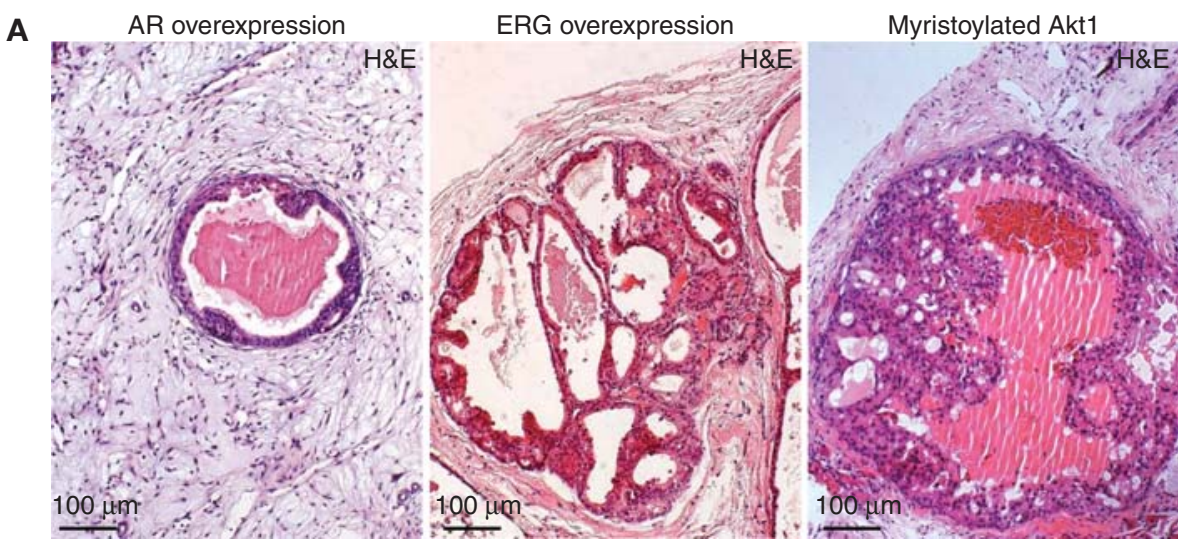

B
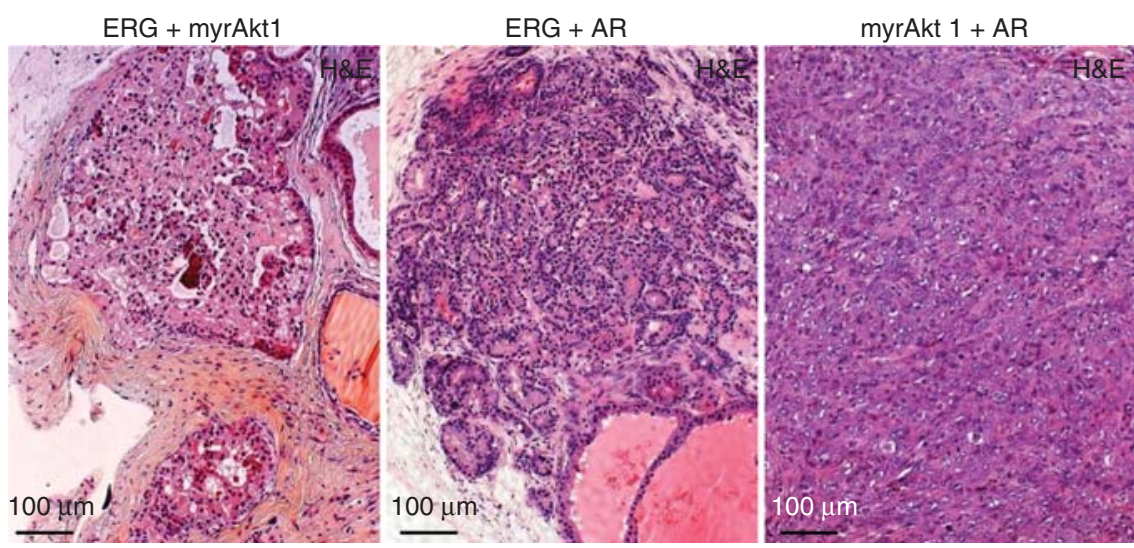

FIGURE 3. Murine PIN and prostate adenocarcinoma induced by defined genetic alterations in the dissociated prostate regeneration model. (A) Histologic analysis of regenerated glands derived from lentiviral-transduced adult mouse prostate epithelial cells, showing that overexpression of ERG or myristoylated Akt1 (myrAkt1) leads to PIN lesions, whereas enhanced AR signaling does not induce any significant neoplastic abnormalities. $(B)$ Mouse prostate adenocarcinoma resulting from different combinations of genetic changes as indicated. 
Moreover, collaborative effects in carcinogenesis are typically assessed by cross-breeding genetically modified animals to generate compound mouse models. However, the cost and time of crossbreeding, as well as matching strain genetic background, can provide significant obstacles. By double infection with different single-gene viral stocks or preparation of a single polycistronic lentiviral vector, various combinations of genetic events can be easily introduced and quickly assessed in the epithelial cells of interest (Xin et al. 2006; Cai et al. 2011a; Drake et al. 2012). Using this efficient strategy, we showed that high levels of ERG protein collaborate with activation of the PI3K/AKT pathway or enhanced AR signaling, resulting in the progression of PIN lesions to frank prostate adenocarcinoma (Zong et al. 2009) (Fig. 3B). In GEMMs, the phenotype of ERG overexpression alone is quite controversial (Klezovitch et al. 2008; Tomlins et al. 2008; Carver et al. 2009; King et al. 2009), possibly because of the distinct isoforms of ERG protein and the different mouse genetic backgrounds used in these studies. Consistent with our results using an ex vivo lentiviral transduction and tissue regeneration approach (Zong et al. 2009), several independent groups have reported synergistic effects between ERG overexpression and an aberrant PTEN/AKT pathway using the cross-breeding strategy (Carver et al. 2009; King et al. 2009).

The high degree of engineering flexibility of the tissue recombination/transplantation system is exemplified by the ability to achieve temporospatial expression of genetic changes with multiple choices of promoters. Incorporation of tetracycline-inducible technology renders this system more regulatable and reversible, where transcriptional activation of downstream genes is tightly controlled by the binding of tetracycline or its derivative, doxycycline, to the transactivator protein. Using this approach, we have determined the requirement for sustained Src kinase activity in prostate tumor maintenance, showing that murine prostate carcinoma induced by constitutively activated Src mutant is dependent on activated Src signaling (Cai et al. 2011a).

All epithelial cells of a specific lineage in the target organ of GEMMs usually carry the introduced genetic alterations, even though the expression pattern can be mosaic or patchy (Mulholland et al. 2011). In contrast, the intrinsic nature of lentiviral transduction results in only a fraction of the transplanted cells receiving the genetic information to express the gene of interest, whereas the remaining cells are unchanged. Given that human cancers usually originate from few epithelial cells interacting with their neighboring normal counterparts, the mixture of normal and genetically modified cells provides the tissue recombination system a unique advantage for more closely modeling cancer initiation within a normal background.

In addition, the availability of linked color markers in lentiviral vectors can facilitate phenotypic analyses and metastasis tracking. By monitoring the dynamic changes in fluorescent or bioluminescent signals, tumor responses to anticancer drugs can be noninvasively followed in host mice. Fluorescence also provides a useful marker to distinguish and purify cancerous cells from adjacent normal epithelium by flow cytometry-based methods for serial transplantation into recipient mice.

The versatility of the tissue recombination/transplantation model allows researchers to address a variety of important questions related to cancer initiation and progression. By genetically manipulating distinct subsets or populations of epithelial cells, the action of an oncogene in different target cells can be readily evaluated in the absence of cell-type or lineage-specific promoters. Previous studies in our laboratory used this strategy to directly compare the in vivo responses of purified prostate basal cells (Lin-Sca-1 + CD49f ${ }^{\text {hi }}$ ) and their luminal counterparts (Lin-Sca-1-CD49f $f^{\text {low }}$ ) to multiple oncogenic stimuli, and showed that murine basal cells are efficient targets for prostate cancer initiation (Lawson et al. 2010). Alternatively, the cells of origin for solid tumors have also been explored using GEMMs. For example, recent studies using an in vivo lineage tracing approach and the cross-breeding strategy showed that not only prostate stem cells with basal characteristics but also some stem cells/ progenitors within the luminal lineage are susceptible to malignant transformation induced by Pten deletion (Wang et al. 2009; Choi et al. 2012). However, the GEMM approach is typically more expensive and relies largely on the specificity of the promoters.

In addition to testing the cell-intrinsic function of genetic changes, the tissue recombination/ transplantation model offers a unique platform to investigate microenvironmental influences in tumorigenesis. By introducing various genetic changes and epigenetic alterations into multiple cellular 
components of the stroma, the contribution of the tumor microenvironment to cancer initiation and progression can be dissected. Using UGSM cells engineered to overexpress fibroblast growth factor 10 (FGF10), we showed that enhanced mesenchymal expression of FGF10 led to the formation of multifocal PIN or prostate adenocarcinoma in the adjacent epithelium, and the disease was serially transplantable with no requirement of continuous exposure to high levels of this paracrine growth factor (Memarzadeh et al. 2007). These data suggest that epithelial cancers can be solely initiated by genetic alterations in the stroma, preceding any subsequent mutations in adjacent epithelial cells. Reciprocally, it has been reported that prolonged activation of FGF receptor 1 in murine prostate epithelia with chemical inducers of dimerization causes disease progression from PIN to adenocarcinoma (Acevedo et al. 2007).

By orthotopically engrafting cancer cells into different recipient mice harboring distinct somatic mutations or into host strains of distinct genetic backgrounds, it is possible to define the relative contribution of each cellular component in the tumor microenvironment as well as the role of germline variability on biological phenotypes. For example, in a recent study, primary mammary carcinoma cells from murine MMTV-Erbb2 tumors were injected into the MFP of wild-type, $\mathrm{Rag}^{-/-}, \mathrm{CD} 4^{-1-}$, and $\mathrm{CD}^{-1-}$ mice. Pulmonary metastasis was found to be significantly diminished in $\mathrm{Rag}^{-1-}$ and $\mathrm{CD}^{-1-}$ mice, but unaltered in $\mathrm{CD}^{-1-}$ mice when compared with wild-type mice, indicating that $\mathrm{CD}^{+}{ }^{+} \mathrm{T}$ cells promote metastasis in this mouse model of breast cancer (Tan et al. 2011).

Although the tissue recombination/transplantation system offers a relatively inexpensive approach for testing a wide range of genetic alterations, cell types, and microenvironmental influences, this model cannot recapitulate all aspects of the genetics, heterogeneous context, and complex biology of human cancers. For example, propagation of genetically manipulated tissue recombinants in immunocompromised mice may prohibit the effects of the host immune response. The potential biases introduced through physical dissociation, lentiviral transduction, and transplantation could also cause discrepancies. In the tissue recombination/transplantation model, cancer initiation and tissue regeneration usually occur simultaneously, which may not reflect the condition of cancer development in humans. However, using the doxycycline-inducible technique, it is possible to overcome this shortcoming by uncoupling cancer initiation from the tissue regeneration process (Cai et al. 2011a). In addition, owing to the multistep procedure, the tissue recombination/transplantation approach is labor intensive and technically demanding, and great care needs to be taken at all steps to minimize the variability.

\section{HUMAN TISSUE RECOMBINATION STRATEGIES TO CONVERT BENIGN HUMAN EPITHELIA TO CANCER}

Although both GEMM and mouse tissue recombination/transplantation models of cancer shed light on the cellular basis and molecular mechanisms for the development of human cancers, it is well recognized that there are fundamental differences in many aspects of cancer biology between mice and humans. These differences include telomere dynamics, related DNA repair mechanisms, and other factors yet to be discovered. The transforming ability of the same genetic events can be different between target cells of mouse and human origin (Rangarajan and Weinberg 2003; Heyer et al. 2010). Additionally, certain ligand-receptor interactions are incompatible across species, such as human hepatocyte growth factor (HGF) receptor (also called MET), which does not bind with the mouse HGF ligand (Rong et al. 1992).

Human cancer cell lines derived from primary or metastatic tumors can be useful for solving the issue of cross-species differences. However, the limited collection of such cell lines and the potential artifacts introduced during long-term culture can complicate results. Primary benign human tissue can serve as an alternative source of starting materials to study cancer development in orthotopic transplantation-based mouse models of human cancers. By genetically manipulating primary benign cells freshly isolated from human donor tissues, the biological consequences of a range of genetic alterations can be tested singly or in combinations using the tissue recombination/transplantation technique. Recently, we successfully established a direct in vivo transformation assay starting with naïve human prostate epithelial cells (Goldstein et al. 2010, 2011). Using an ex vivo lentiviral trans- 
duction and in vivo regeneration approach, we showed that CD49f ${ }^{\text {hi }}$ Trop 2 hi basal cells from primary benign human prostate tissue can initiate prostate cancer in immunodeficient mice. The cooperative effects of AKT, ERG, and AR in basal cells closely recapitulated the histologic and molecular features of human prostate cancer, with loss of basal cells and expansion of luminal cells expressing prostatespecific antigen and $\alpha$-methylacyl-CoA racemase (Goldstein et al. 2010). These findings suggest that basal cells are one cell type of origin in human prostate cancer.

Using primary, noncancerous human epithelial cells, several human-in-mouse models of skin carcinoma, melanoma, and breast cancer have been developed in a similar fashion to study the cellautonomous roles of oncogenic events (Fan et al. 1997; Khavari 2006; Wu et al. 2009). In addition, microenvironmental influences in carcinogenesis have also been examined in a human mammary reconstitution system, where the mouse MFP of SCID mice is "humanized" by introducing human mammary fibroblasts, thus facilitating proper colonization and growth of human mammary epithelial cells in the chimeric stroma (Kuperwasser et al. 2004). In this system, genetic modification of human mammary fibroblasts to overexpress either HGF or TGF- $\beta 1$ results in the outgrowth of malignant lesions from a cell preparation of morphologically normal human mammary epithelia (Kuperwasser et al. 2004).

\section{CONCLUSIONS}

The tissue recombination/transplantation model is a very powerful system with a high degree of flexibility that enables its use for broad applications. Certain questions about the tissue recombination model still need to be resolved, including the effects of the loss of cell-cell contact during tissue dissociation and lentiviral transduction. Despite a few limitations, this model can faithfully recapitulate the biology and context of human solid tumors in a fast and cost-effective manner. By testing the effects of a wide range of genetic events and epigenetic changes on the same target material, this approach bypasses any concerns about genetic background. Therefore, distinct genetic alterations and pathway activation can be compared in a common setting. As recent studies suggest that epithelial cancers may arise from the transformation of multiple distinct cells of origin, the tissue recombination approach allows for direct comparisons of common genetic alterations expressed in different target cells. Most important, this approach allows for parallel investigation of cancer initiation and progression in both rodent and human tissues. In summary, the tissue recombination/transplantation model provides a unique platform for the functional validation of candidate target genes and the development of anticancer drugs.

\section{ACKNOWLEDGMENTS}

We thank the former and current members of the Witte laboratory for their help and contribution. O.N.W. is an investigator and Y.Z. is an associate of the Howard Hughes Medical Institute. A.S.G. is supported by the Prostate Cancer Foundation and the Broad Stem Cell Research Center at the University of California, Los Angeles.

\section{REFERENCES}

Acevedo VD, Gangula RD, Freeman KW, Li R, Zhang Y, Wang F, Ayala GE, Peterson LE, Ittmann M, Spencer DM. 2007. Inducible FGFR-1 activation leads to irreversible prostate adenocarcinoma and an epithelial-tomesenchymal transition. Cancer Cell 12: 559-571.

Al-Hajj M, Wicha MS, Benito-Hernandez A, Morrison SJ, Clarke MF. 2003. Prospective identification of tumorigenic breast cancer cells. Proc Natl Acad Sci 100: 3983-3988.

Alescio T, Cassini A. 1962. Induction in vitro of tracheal buds by pulmonary mesenchyme grafted on tracheal epithelium. J Exp Zool 150: 83-94.
Asselin-Labat ML, Vaillant F, Sheridan JM, Pal B, Wu D, Simpson ER, Yasuda H, Smyth GK, Martin TJ, Lindeman GJ, et al. 2010. Control of mammary stem cell function by steroid hormone signalling. Nature 465: 798-802.

Auerbach R. 1960. Morphogenetic interactions in the development of the mouse thymus gland. Dev Biol 2: 271-284.

Barcellos-Hoff MH, Ravani SA. 2000. Irradiated mammary gland stroma promotes the expression of tumorigenic potential by unirradiated epithelial cells. Cancer Res 60: 1254-1260. 
Bhowmick NA, Neilson EG, Moses HL. 2004. Stromal fibroblasts in cancer initiation and progression. Nature 432: 332-337.

Bissell MJ, Hines WC. 2011. Why don't we get more cancer? A proposed role of the microenvironment in restraining cancer progression. Nat Med 17: $320-329$.

Bradbury JM, Arno J, Edwards PA. 1993. Induction of epithelial abnormalities that resemble human breast lesions by the expression of the neu/ erbB-2 oncogene in reconstituted mouse mammary gland. Oncogene 8: 1551-1558.

Bradbury JM, Edwards PA, Niemeyer CC, Dale TC. 1995. Wnt-4 expression induces a pregnancy-like growth pattern in reconstituted mammary glands in virgin mice. Dev Biol 170: 553-563.

Brisken C, Park S, Vass T, Lydon JP, O’Malley BW, Weinberg RA. 1998. A paracrine role for the epithelial progesterone receptor in mammary gland development. Proc Natl Acad Sci 95: 5076-5081.

Cai H, Babic I, Wei X, Huang J, Witte ON. 2011a. Invasive prostate carcinoma driven by c-Src and androgen receptor synergy. Cancer Res 71: 862-872.

Cai H, Smith DA, Memarzadeh S, Lowell CA, Cooper JA, Witte ON. 2011b. Differential transformation capacity of Src family kinases during the initiation of prostate cancer. Proc Natl Acad Sci 108: 6579-6584.

Capella G, Farre L, Villanueva A, Reyes G, Garcia C, Tarafa G, Lluis F. 1999. Orthotopic models of human pancreatic cancer. Ann NY Acad Sci 880: 103-109.

Carver BS, Tran J, Gopalan A, Chen Z, Shaikh S, Carracedo A, Alimonti A, Nardella C, Varmeh S, Scardino PT, et al. 2009. Aberrant ERG expression cooperates with loss of PTEN to promote cancer progression in the prostate. Nat Genet 41: 619-624.

Chan E, Patel A, Heston W, Larchian W. 2009. Mouse orthotopic models for bladder cancer research. BJU Int 104: 1286-1291.

Choi N, Zhang B, Zhang L, Ittmann M, Xin L. 2012. Adult murine prostate basal and luminal cells are self-sustained lineages that can both serve as targets for prostate cancer initiation. Cancer Cell 21: 253-265.

Condeelis J, Weissleder R. 2010. In vivo imaging in cancer. Cold Spring Harb Perspect Biol 2: a003848.

Cunha GR. 1972a. Epithelio-mesenchymal interactions in primordial gland structures which become responsive to androgenic stimulation. Anat Rec 172: 179-195.

Cunha GR. 1972b. Support of normal salivary gland morphogenesis by mesenchyme derived from accessory sexual glands of embryonic mice. Anat Rec 173: 205-212.

Cunha GR. 1972c. Tissue interactions between epithelium and mesenchyme of urogenital and integumental origin. Anat Rec 172: 529-541.

Cunha GR. 2008. Mesenchymal-epithelial interactions: Past, present, and future. Differentiation 76: 578-586.

Cunha GR, Lung B. 1978. The possible influence of temporal factors in androgenic responsiveness of urogenital tissue recombinants from wild-type and androgen-insensitive (Tfm) mice. J Exp Zool 205: 181193.

Cunha GR, Chung LW, Shannon JM, Reese BA. 1980. Stromal-epithelial interactions in sex differentiation. Biol Reprod 22: 19-42.

Daley GQ, Van Etten RA, Baltimore D. 1990. Induction of chronic myelogenous leukemia in mice by the P210 ${ }^{b c r / a b l}$ gene of the Philadelphia chromosome. Science 247: 824-830.

Deome KB, Faulkin LJ Jr, Bern HA, Blair PB. 1959. Development of mammary tumors from hyperplastic alveolar nodules transplanted into gland-free mammary fat pads of female $\mathrm{C} 3 \mathrm{H}$ mice. Cancer Res 19: $515-520$

Deramaudt TB, Takaoka M, Upadhyay R, Bowser MJ, Porter J, Lee A, Rhoades B, Johnstone CN, Weissleder R, Hingorani SR, et al. 2006. $\mathrm{N}$-cadherin and keratinocyte growth factor receptor mediate the functional interplay between Ki-RASG12V and p53V143A in promoting pancreatic cell migration, invasion, and tissue architecture disruption. Mol Cell Biol 26: 4185-4200.

Dorshkind K, Keller GM, Phillips RA, Miller RG, Bosma GC, O’Toole M, Bosma MJ. 1984. Functional status of cells from lymphoid and myeloid tissues in mice with severe combined immunodeficiency disease. J Immunol 132: 1804-1808.

Drake JM, Graham NA, Stoyanova T, Sedghi A, Goldstein AS, Cai H, Smith DA, Zhang H, Komisopoulou E, Huang J, et al. 2012. Oncogene-specific activation of tyrosine kinase networks during prostate cancer progression. Proc Natl Acad Sci 109: 1643-1648.
Edwards PA, Ward JL, Bradbury JM. 1988. Alteration of morphogenesis by the v-myc oncogene in transplants of mammary gland. Oncogene 2: $407-412$.

Edwards PA, Hiby SE, Papkoff J, Bradbury JM. 1992. Hyperplasia of mouse mammary epithelium induced by expression of the Wnt-1 (int-1) oncogene in reconstituted mammary gland. Oncogene 7: 2041-2051.

Edwards PA, Abram CL, Bradbury JM. 1996. Genetic manipulation of mammary epithelium by transplantation. J Mammary Gland Biol Neoplasia 1: 75-89.

Fan H, Oro AE, Scott MP, Khavari PA. 1997. Induction of basal cell carcinoma features in transgenic human skin expressing Sonic Hedgehog. Nat Med 3: 788-792.

Fleischmajer R. 1967. Epithelial-mesenchymal interactions. Science 157: $1472-1482$.

Fleming JM, Miller TC, Meyer MJ, Ginsburg E, Vonderhaar BK. 2010. Local regulation of human breast xenograft models. J Cell Physiol 224: 795806.

Francia G, Cruz-Munoz W, Man S, Xu P, Kerbel RS. 2011. Mouse models of advanced spontaneous metastasis for experimental therapeutics. Nat Rev Cancer 11: 135-141.

Gallego MI, Binart N, Robinson GW, Okagaki R, Coschigano KT, Perry J, Kopchick JJ, Oka T, Kelly PA, Hennighausen L. 2001. Prolactin, growth hormone, and epidermal growth factor activate Stat5 in different compartments of mammary tissue and exert different and overlapping developmental effects. Dev Biol 229: 163-175.

Gallin JI, Bujak JS, Patten E, Wolff SM. 1974. Granulocyte function in the Chediak-Higashi syndrome of mice. Blood 43: 201-206.

Ginestier C, Hur MH, Charafe-Jauffret E, Monville F, Dutcher J, Brown M, Jacquemier J, Viens P, Kleer CG, Liu S, et al. 2007. ALDH1 is a marker of normal and malignant human mammary stem cells and a predictor of poor clinical outcome. Cell Stem Cell 1: 555-567.

Goldstein AS, Lawson DA, Cheng D, Sun W, Garraway IP, Witte ON. 2008. Trop2 identifies a subpopulation of murine and human prostate basal cells with stem cell characteristics. Proc Natl Acad Sci 105: 20882-20887.

Goldstein AS, Huang J, Guo C, Garraway IP, Witte ON. 2010. Identification of a cell of origin for human prostate cancer. Science 329: 568-571.

Goldstein AS, Drake JM, Burnes DL, Finley DS, Zhang H, Reiter RE, Huang J, Witte ON. 2011. Purification and direct transformation of epithelial progenitor cells from primary human prostate. Nat Protoc 6: 656-667.

Grobstein C. 1953a. Epithelio-mesenchymal specificity in the morphogenesis of mouse sub-mandibular rudiments in vitro. J Exp Zool 124: 383-413.

Grobstein C. 1953b. Inductive epitheliomesenchymal interaction in cultured organ rudiments of the mouse. Science 118: 52-55.

Heyer J, Kwong LN, Lowe SW, Chin L. 2010. Non-germline genetically engineered mouse models for translational cancer research. Nat Rev Cancer 10: 470-480.

Hoffman RM. 1999. Orthotopic metastatic mouse models for anticancer drug discovery and evaluation: A bridge to the clinic. Invest New Drugs 17: 343-359.

Joshi PA, Jackson HW, Beristain AG, Di Grappa MA, Mote PA, Clarke CL, Stingl J, Waterhouse PD, Khokha R. 2010. Progesterone induces adult mammary stem cell expansion. Nature 465: 803-807.

Joyce JA, Pollard JW. 2009. Microenvironmental regulation of metastasis. Nat Rev Cancer 9: 239-252.

Kaye AH, Morstyn G, Gardner I, Pyke K. 1986. Development of a xenograft glioma model in mouse brain. Cancer Res 46: 1367-1373.

Kelliher MA, McLaughlin J, Witte ON, Rosenberg N. 1990. Induction of a chronic myelogenous leukemia-like syndrome in mice with $\mathrm{v}-a b l$ and BCR/ABL. Proc Natl Acad Sci 87: 6649-6653.

Khavari PA. 2006. Modelling cancer in human skin tissue. Nat Rev Cancer 6: $270-280$.

Kim MJ, Bhatia-Gaur R, Banach-Petrosky WA, Desai N, Wang Y, Hayward SW, Cunha GR, Cardiff RD, Shen MM, Abate-Shen C. 2002. Nkx3.1 mutant mice recapitulate early stages of prostate carcinogenesis. Cancer Res 62: 2999-3004

King JC, Xu J, Wongvipat J, Hieronymus H, Carver BS, Leung DH, Taylor BS, Sander C, Cardiff RD, Couto SS, et al. 2009. Cooperativity of TMPRSS2-ERG with PI3-kinase pathway activation in prostate oncogenesis. Nat Genet 41: 524-526.

Klezovitch O, Risk M, Coleman I, Lucas JM, Null M, True LD, Nelson PS, Vasioukhin V. 2008. A causal role for ERG in neoplastic transformation of prostate epithelium. Proc Natl Acad Sci 105: 2105-2110. 
Kordon EC, Smith GH. 1998. An entire functional mammary gland may comprise the progeny from a single cell. Development 125: 19211930.

Kroon E, Krosl J, Thorsteinsdottir U, Baban S, Buchberg AM, Sauvageau G. 1998. Hoxa9 transforms primary bone marrow cells through specific collaboration with Meisla but not Pbx1b. EMBO J 17: 3714-3725.

Kuo TH, Kubota T, Watanabe M, Furukawa T, Kase S, Tanino H, Saikawa Y, Ishibiki K, Kitajima M, Hoffman RM. 1993. Site-specific chemosensitivity of human small-cell lung carcinoma growing orthotopically compared to subcutaneously in SCID mice: The importance of orthotopic models to obtain relevant drug evaluation data. Anticancer Res 13: 627630 .

Kuperwasser C, Chavarria T, Wu M, Magrane G, Gray JW, Carey L, Richardson A, Weinberg RA. 2004. Reconstruction of functionally normal and malignant human breast tissues in mice. Proc Natl Acad Sci 101: 4966-4971.

Kuperwasser C, Dessain S, Bierbaum BE, Garnet D, Sperandio K, Gauvin GP, Naber SP, Weinberg RA, Rosenblatt M. 2005. A mouse model of human breast cancer metastasis to human bone. Cancer Res 65: 61306138.

Lawson DA, Xin L, Lukacs RU, Cheng D, Witte ON. 2007. Isolation and functional characterization of murine prostate stem cells. Proc Natl Acad Sci 104: 181-186.

Lawson DA, Zong Y, Memarzadeh S, Xin L, Huang J, Witte ON. 2010. Basal epithelial stem cells are efficient targets for prostate cancer initiation. Proc Natl Acad Sci 107: 2610-2615.

Lawson DA, Werb Z, Zong Y, Goldstein AS. 2014. The cleared mammary fat pad transplantation assay for mammary epithelial organogenesis. Cold Spring Harb Protoc doi: 10.1101/pdb.prot078071.

Lukacs RU, Memarzadeh S, Wu H, Witte ON. 2010. Bmi-1 is a crucial regulator of prostate stem cell self-renewal and malignant transformation. Cell Stem Cell 7: 682-693.

Mallepell S, Krust A, Chambon P, Brisken C. 2006. Paracrine signaling through the epithelial estrogen receptor alpha is required for proliferation and morphogenesis in the mammary gland. Proc Natl Acad Sci 103: 2196-2201.

Man AK, Young LJ, Tynan JA, Lesperance J, Egeblad M, Werb Z, Hauser CA, Muller WJ, Cardiff RD, Oshima RG. 2003. Ets2-dependent stromal regulation of mouse mammary tumors. Mol Cell Biol 23: 8614-8625.

McConnell G. 1908. The transplantation of human carcinomatous material into lower animals. J Exp Med 10: 36-44.

Medina D. 2010. Of mice and women: A short history of mouse mammary cancer research with an emphasis on the paradigms inspired by the transplantation method. Cold Spring Harb Perspect Biol 2: a004523.

Memarzadeh S, Xin L, Mulholland DI, Mansukhani A, Wu H, Teitell MA, Witte ON. 2007. Enhanced paracrine FGF10 expression promotes formation of multifocal prostate adenocarcinoma and an increase in epithelial androgen receptor. Cancer Cell 12: 572-585.

Memarzadeh S, Zong Y, Janzen DM, Goldstein AS, Cheng D, Kurita T, Schafenacker AM, Huang J, Witte ON. 2010. Cell-autonomous activation of the PI3-kinase pathway initiates endometrial cancer from adult uterine epithelium. Proc Natl Acad Sci 107: 17298-17303.

Mulholland DJ, Tran LM, Li Y, Cai H, Morim A, Wang S, Plaisier S, Garraway IP, Huang J, Graeber TG, et al. 2011. Cell autonomous role of PTEN in regulating castration-resistant prostate cancer growth. Cancer Cell 19: 792-804.

Munoz R, Man S, Shaked Y, Lee CR, Wong J, Francia G, Kerbel RS. 2006. Highly efficacious nontoxic preclinical treatment for advanced metastatic breast cancer using combination oral UFT-cyclophosphamide metronomic chemotherapy. Cancer Res 66: 3386-3391.

Nakajima M, Morikawa K, Fabra A, Bucana CD, Fidler IJ. 1990. Influence of organ environment on extracellular matrix degradative activity and metastasis of human colon carcinoma cells. J Natl Cancer Inst 82: $1890-1898$.

Nakasone ES, Askautrud HA, Kees T, Park JH, Plaks V, Ewald AJ, Fein M, Rasch MG, Tan YX, Qiu J, et al. 2012. Imaging tumor-stroma interactions during chemotherapy reveals contributions of the microenvironment to resistance. Cancer Cell 21: 488-503.

Neville MC, Medina D, Monks J, Hovey RC. 1998. The mammary fat pad. J Mammary Gland Biol Neoplasia 3: 109-116.
Norman JT, Cunha GR, Sugimura Y. 1986. The induction of new ductal growth in adult prostatic epithelium in response to an embryonic prostatic inductor. Prostate 8: 209-220.

Pantelouris EM. 1968. Absence of thymus in a mouse mutant. Nature 217: 370-371.

Puzio-Kuter AM, Castillo-Martin M, Kinkade CW, Wang X, Shen TH, Matos T, Shen MM, Cordon-Cardo C, Abate-Shen C. 2009. Inactivation of p53 and Pten promotes invasive bladder cancer. Genes Dev 23: 675-680.

Rangarajan A, Weinberg RA. 2003. Opinion: Comparative biology of mouse versus human cells: Modelling human cancer in mice. Nat Rev Cancer 3: 952-959.

Roder JC. 1979. The beige mutation in the mouse. I. A stem cell predetermined impairment in natural killer cell function. J Immunol 123: 2168 2173.

Rong S, Bodescot M, Blair D, Dunn J, Nakamura T, Mizuno K, Park M, Chan A, Aaronson S, Vande Woude GF. 1992. Tumorigenicity of the met proto-oncogene and the gene for hepatocyte growth factor. Mol Cell Biol 12: 5152-5158.

Sakakura T, Sakagami Y, Nishizuka Y. 1982. Dual origin of mesenchymal tissues participating in mouse mammary gland embryogenesis. Dev Biol 91: 202-207.

Sakakura T, Kusano I, Kusakabe M, Inaguma Y, Nishizuka Y. 1987. Biology of mammary fat pad in fetal mouse: Capacity to support development of various fetal epithelia in vivo. Development 100: 421-430.

Shackleton M, Vaillant F, Simpson KJ, Stingl J, Smyth GK, Asselin-Labat ML, Wu L, Lindeman GJ, Visvader JE. 2006. Generation of a functional mammary gland from a single stem cell. Nature 439: 84-88.

Sharpless NE, Depinho RA. 2006. The mighty mouse: Genetically engineered mouse models in cancer drug development. Nat Rev Drug Discov 5: 741-754.

Shin S, Kim TD, Jin F, van Deursen JM, Dehm SM, Tindall DJ, Grande JP, Munz JM, Vasmatzis G, Janknecht R. 2009. Induction of prostatic intraepithelial neoplasia and modulation of androgen receptor by ETS variant 1/ETS-related protein 81 . Cancer Res 69: 81028110.

Shultz LD, Schweitzer PA, Christianson SW, Gott B, Schweitzer IB, Tennent B, McKenna S, Mobraaten L, Rajan TV, Greiner DL, et al. 1995. Multiple defects in innate and adaptive immunologic function in NOD/ LtSz-scid mice. J Immunol 154: 180-191.

Shultz LD, Lyons BL, Burzenski LM, Gott B, Chen X, Chaleff S, Kotb M, Gillies SD, King M, Mangada J, et al. 2005. Human lymphoid and myeloid cell development in NOD/LtSz-scid IL2R gamma null mice engrafted with mobilized human hemopoietic stem cells. J Immunol 174: 6477-6489.

Stingl J, Eirew P, Ricketson I, Shackleton M, Vaillant F, Choi D, Li HI, Eaves CJ. 2006. Purification and unique properties of mammary epithelial stem cells. Nature 439: 993-997.

Talmadge JE, Singh RK, Fidler IJ, Raz A. 2007. Murine models to evaluate novel and conventional therapeutic strategies for cancer. Am J Pathol 170: 793-804.

Tan W, Zhang W, Strasner A, Grivennikov S, Cheng JQ, Hoffman RM, Karin M. 2011. Tumour-infiltrating regulatory $\mathrm{T}$ cells stimulate mammary cancer metastasis through RANKL-RANK signalling. Nature 470: 548553.

Tomlins SA, Laxman B, Dhanasekaran SM, Helgeson BE, Cao X, Morris DS, Menon A, Jing X, Cao Q, Han B, et al. 2007. Distinct classes of chromosomal rearrangements create oncogenic ETS gene fusions in prostate cancer. Nature 448: 595-599.

Tomlins SA, Laxman B, Varambally S, Cao X, Yu J, Helgeson BE, Cao Q, Prensner JR, Rubin MA, Shah RB, et al. 2008. Role of the TMPRSS2ERG gene fusion in prostate cancer. Neoplasia 10: 177-188.

Van Keymeulen A, Rocha AS, Ousset M, Beck B, Bouvencourt G, Rock J, Sharma N, Dekoninck S, Blanpain C. 2011. Distinct stem cells contribute to mammary gland development and maintenance. Nature 479: 189-193.

Wang Y, Hayward SW, Donjacour AA, Young P, Jacks T, Sage J, Dahiya R, Cardiff RD, Day ML, Cunha GR. 2000. Sex hormone-induced carcinogenesis in Rb-deficient prostate tissue. Cancer Res 60: 6008-6017.

Wang X, Kruithof-de Julio M, Economides KD, Walker D, Yu H, Halili MV, Hu YP, Price SM, Abate-Shen C, Shen MM. 2009. A luminal epithelial stem cell that is a cell of origin for prostate cancer. Nature 461: 495-500. 
Weissleder R. 2002. Scaling down imaging: Molecular mapping of cancer in mice. Nat Rev Cancer 2: 11-18.

Wernig G, Mercher T, Okabe R, Levine RL, Lee BH, Gilliland DG. 2006. Expression of Jak2V617F causes a polycythemia vera-like disease with associated myelofibrosis in a murine bone marrow transplant model. Blood 107: 4274-4281.

Wiesen JF, Young P, Werb Z, Cunha GR. 1999. Signaling through the stromal epidermal growth factor receptor is necessary for mammary ductal development. Development 126: 335-344.

Woolley GW. 1958. The human tumor in heterologous hosts-Discussion. Ann NY Acad Sci 76: 821-825.

Wu M, Jung L, Cooper AB, Fleet C, Chen L, Breault L, Clark K, Cai Z, Vincent S, Bottega S, et al. 2009. Dissecting genetic requirements of human breast tumorigenesis in a tissue transgenic model of human breast cancer in mice. Proc Natl Acad Sci 106: 7022-7027.

Xin L, Ide H, Kim Y, Dubey P, Witte ON. 2003. In vivo regeneration of murine prostate from dissociated cell populations of postnatal epithelia and urogenital sinus mesenchyme. Proc Natl Acad Sci 100: 11896- 11903.

Xin L, Lawson DA, Witte ON. 2005. The Sca-1 cell surface marker enriches for a prostate-regenerating cell subpopulation that can initiate prostate tumorigenesis. Proc Natl Acad Sci 102: 6942-6947.
Xin L, Teitell MA, Lawson DA, Kwon A, Mellinghoff IK, Witte ON. 2006. Progression of prostate cancer by synergy of AKT with genotropic and nongenotropic actions of the androgen receptor. Proc Natl Acad Sci 103: 7789-7794.

Yang M, Jiang P, Sun FX, Hasegawa S, Baranov E, Chishima T, Shimada H, Moossa AR, Hoffman RM. 1999. A fluorescent orthotopic bone metastasis model of human prostate cancer. Cancer Res 59: 781-786.

Zhang M, Behbod F, Atkinson RL, Landis MD, Kittrell F, Edwards D, Medina D, Tsimelzon A, Hilsenbeck S, Green JE, et al. 2008. Identification of tumor-initiating cells in a p53-null mouse model of breast cancer. Cancer Res 68: 4674-4682.

Zong Y, Xin L, Goldstein AS, Lawson DA, Teitell MA, Witte ON. 2009. ETS family transcription factors collaborate with alternative signaling pathways to induce carcinoma from adult murine prostate cells. Proc Natl Acad Sci 106: 12465-12470.

Zong Y, Goldstein AS, Witte ON. 2014a. Preparation of urogenital sinus mesenchymal cells for prostate tissue recombination models. Cold Spring Harb Protoc doi: 10.1101/pdb.prot078055.

Zong Y, Goldstein AS, Witte ON. 2014b. Dissociated prostate regeneration under the renal capsule. Cold Spring Harb Protoc doi: 10.1101/pdb. prot078063. 


\section{Tissue Recombination Models for the Study of Epithelial Cancer}

Yang Zong, Andrew S. Goldstein and Owen N. Witte

Cold Spring Harb Protoc; doi: 10.1101/pdb.top069880

\begin{tabular}{cc}
$\begin{array}{r}\text { Email Alerting } \\
\text { Service }\end{array}$ & Receive free email alerts when new articles cite this article - click here. \\
\hline $\begin{array}{c}\text { Subject } \\
\text { Categories }\end{array}$ & $\begin{array}{c}\text { Browse articles on similar topics from Cold Spring Harbor Protocols. } \\
\text { Mouse (437 articles) }\end{array}$ \\
\hline
\end{tabular}

